\title{
Occurrence of Drynaria sparsisora (Desv.) T. Moore, in the lower Hantana area, Sri Lanka
}

\author{
R.H.G. Ranil ${ }^{1 *}$ and D.K.N.G. Pushpakumara ${ }^{2}$ \\ I Postgraduate Institute of Agriculture, University of Peradeniya, Peradeniya. \\ 2 Department of Crop Science, Faculty of Agriculture, University of Peradeniya, Peradeniya.
}

Revised: 23 June 2008 ; Accepted: 11 August 2008

\begin{abstract}
Drynaria sparsisora (Desv.) T. Moore was observed in the lower Hantana area after 56 years. A cytological study and continuation of morphological observation of sori is suggested to confirm the occurrence of $D$. sparsisora in the lower Hantana area.
\end{abstract}

Keywords: Drynaria sparsisora, Drynaria quercifolia, ferns, Hantana, pteridophytes.

\section{INTRODUCTION}

Out of about 11,300 pteridophyte species recordered worldwide $^{1}, 362$ species have been reported from Sri Lanka $^{2}$. Due to various threats, 90 local species are considered to be threatened. It has been reported that 13 species of ferns from Sri Lanka are already extinct and more than 30 species of pteridophytes have not been collected during the last century ${ }^{3}$. The specimens in the National Herbarium in the Royal Botanical Gardens, Peradeniya and the literature revealed that the Hantana range provides a natural refugium for Pteridophyte species that are extremely rare and possibly extinct in other localities in the island ${ }^{4-7}$. For example, two fern species namely, Pronephrium gardneri Holttum (Thelypteridaceae) and Pteridrys zeylanica Ching. (Dryopteridaceae) have been recorded from the Hantana range during 1883-1890. These two species have not been recorded during the last century ${ }^{6-7}$. Although such evidences suggest that the Hantana range is one of the sensitive areas of the Central Highland in the country, only limited studies (i.e. Perera et ${ }^{8}{ }^{8}$;Subasinghe et al. ${ }^{9}$ ) have been carried out on the biodiversity of pteridophytes of the Hantana range. The objective of this study was to provide information on the observation of the presence of a rare and supposedly extinct fern species from lower Hantana area.

\section{METHOD AND MATERIALS}

During a field visit to the Hantana range, specimens resembling Drynaria sparsisora (Desv.) T. Moore were observed along the banks of a stream. Morphological characters of both nest and foliage fronds and rhizome of the observed specimen and known specimens of $D$. quercifolia (L.) J. Smith were measured and recorded. Scales of the observed specimen and known samples of $D$. quercifolia were also observed using a light microscope $(\times 100)$ and line diagrams were drawn. Literature on the genus Drynaria was reviewed to obtain the historical records. Scientists studying the family Polypodiaceae were consulted for the identification of Drynaria species.

\section{RESULTS AND DISCUSSION}

The genus Drynaria is represented in Sri Lanka by two species namely, D. quercifolia and D. sparsisora $^{10}$. Drynaria quercifolia is the most common species found in Sri Lanka which is commonly known as Benduru. It had originally been collected by Paul Herman from Sri Lanka and described by Linnaeus ${ }^{11}$. It usually grows on trees as an epiphyte or on rocks as a lithophyte in the Central, Western and Southern Provinces up to an elevation of $900 \mathrm{~m}^{11}$. In addition to Sri Lanka, D. quercifolia has been observed in India and Southern China, throughout Southeast Asia to tropical Australia and Polynesia ${ }^{12}$. The species is used to prepare oil which is useds as an in indigenous medicine, and also as an ornamental plant ${ }^{13}$.

In contrast, D. sparsisora is considered a rare species in Sri Lanka ${ }^{10,14}$. In addition to Sri Lanka, it has 
also been found throughout Southeast Asia, Southern China, tropical Australia and Polynesia ${ }^{11}$. The orginal report of the occurrence of this species in Sri Lanka was based on a single herbarium sheet at the Kew Herbarium, UK which was labeleed "Ceylon"with no other details. Even though the specimen was not adequately labeled it was identified as D. sparsisora. According to Sledge ${ }^{10}$, there are no other Sri Lankan or Indian specimens in the National Herbarium in Peradeniya or in the British Museum, UK and therefore he had suggested that the evidence for the occurrence of D. sparsisora in Sri Lanka was inadequate. However, Hovenkamp ${ }^{15}$, while revising the family Polypodiaceae in Sri Lanka had found three other specimens of D. sparsisora from the Kew Herbarium that were collected from Sri Lanka in 19501951 by Ballard, but no spores were observed in all three specimens. Hovenkamp ${ }^{15}$ later identified these specimens as D. sparsisora based on scale characters of the rhizome. Details of information of the four specimens identified as D. sparsisora in the Kew Herbarium are given in Table 1.

It is clear from the literature that both $D$. quercifolia (Plate 1) and D. sparsisora (Plate 2) closely resemble each other. However, scales on the rhizome and sori arrangement are unique to each species ${ }^{11,16}$. A comparison of scale characters of rhizome and sori of $D$. quercifolia

Figure 1: Scales observed from rhizome of Drynaria species (mag. x100).

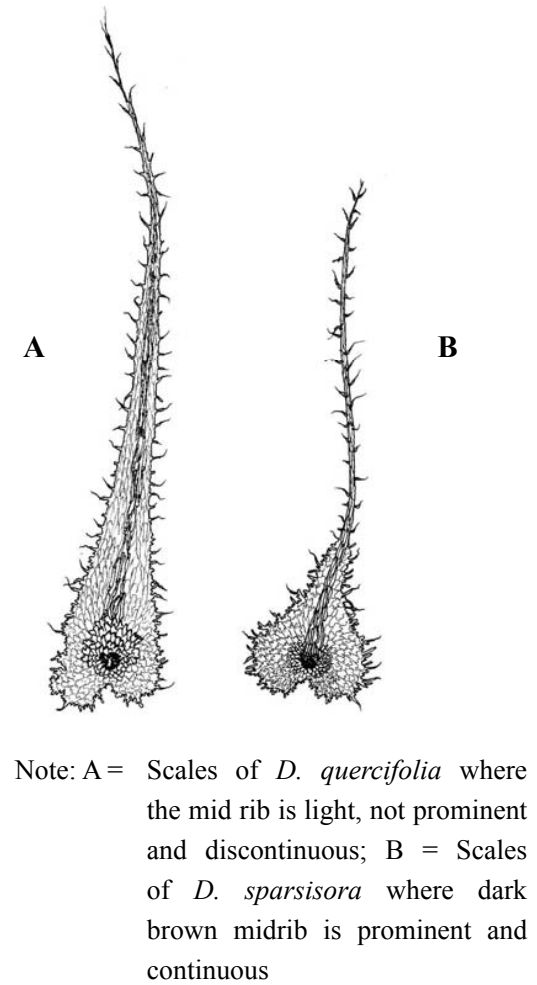

and D. sparsisora is illustrated in Figures 1 and 2. According to the available literature and the specimens kept at the National Herbarium, it is suggested that D. sparsisora has not been recorded from Sri Lanka during the last 56 years.

\section{Observation of $D$. sparsisora after 56 years}

A group of about 10 plants of $D$. sparsisora (Plate 2) were observed on a rock crevice close to a stream bank of the lower Hantane area in Kandy District. The voucher specimen (850R) was deposited in the Pteridological collection of the Faculty of Agriculture, University of Peradeniya. The morphological characters of the observed plants are given below.

Rhizome characters: The observed specimens had a short, thick and creeping rhizome which was covered with dark brown, peltate shaped scales. A dark brown prominent midrib was observed on the scales as illustrated in Figure 1B. In contrast, D. quercifolia scales usually has no prominent midrib (Figure 1A).

Frond characters: The observed specimens had two types of fronds the foliage fronds and the base fronds. Foliage frond had leathery lamina with long wingedpetioles (lengths ranged from 27.5 to $39 \mathrm{~cm}$ ). The frond lamina was deeply pinnate consisting of 7- 11 pairs of lobes. Length and width of frond lamina ranged from 64 to $105 \mathrm{~cm}$ and from 40 to $58 \mathrm{~cm}$, respectively. Nest leaves (base fronds) were sessile and entire, and with shallowly or deeply lobed margins. The width of base fronds varied from 12 to $19 \mathrm{~cm}$ and length varied from 13 to $23 \mathrm{~cm}$. Veins of base fronds were reticulate between two main lateral veins. Free veinlets were simple or absent. According to Beddome ${ }^{16}$, Sledge ${ }^{13}$, Winter and Amoroso $^{11}$ there are no significant differences between the nest and foliage frond characters of $D$. quercifolia and D. sparsisora.

Figure 2: Sori arrangement of two Drynaria species (mag. x2).

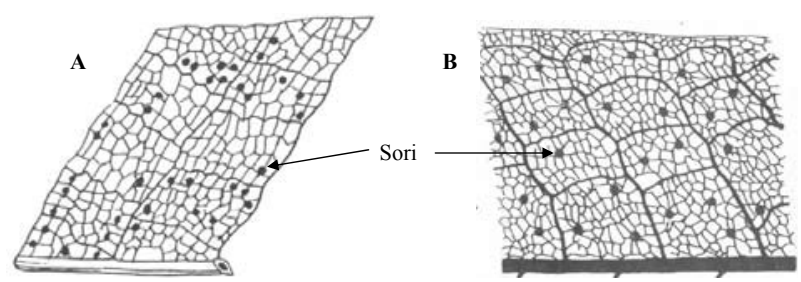

Note: $\mathrm{A}=D$. sparsisora with scattered or irregular row arrangement $\mathrm{t}^{16}$; $B=D$. quercifolia with sori arrangement in two regular rows $^{17}$ 
Sori arrangement: All specimens consisted of juvenile foliage fronds and thus, sori were not observed in any plant. However, according to Hovenkamp ${ }^{15}$ and Winter and Amoroso $^{11}$, the sori of $D$. sparsisora are rounded slightly sunken and 1-2 mm in diameter. In general, 2-7 sori are arranged in each areole irregularly scattered or in

Table 1: Descriptions of specimens of Drynaria sparsisora, collected from Sri Lanka and deposited at the Kew Herbarium.

\begin{tabular}{|c|c|c|c|}
\hline Specimen No. & Locality & Date & Collector \\
\hline-- & Stated as Ceylon & Not stated & Not stated \\
\hline 1095 & $\begin{array}{l}\text { Kandy District, Kadugannawa, } \\
62 \text { mile post, on Colombo-Kandy road. }\end{array}$ & 12 Dec. 1950 & Ballard \\
\hline 1370 & $\begin{array}{l}\text { Ratnapura District, Belihul oya, in } \\
\text { crevice in granite in stream by rest house }\end{array}$ & 03 Jan. 1951 & Ballard \\
\hline 1371 & $\begin{array}{l}\text { Ratnapura District, Belihul oya, on } \\
\text { dead tree trunk, near rest house }\end{array}$ & 03 Jan. 1951 & Ballard \\
\hline
\end{tabular}

Source: Hovenkamp ${ }^{15}$

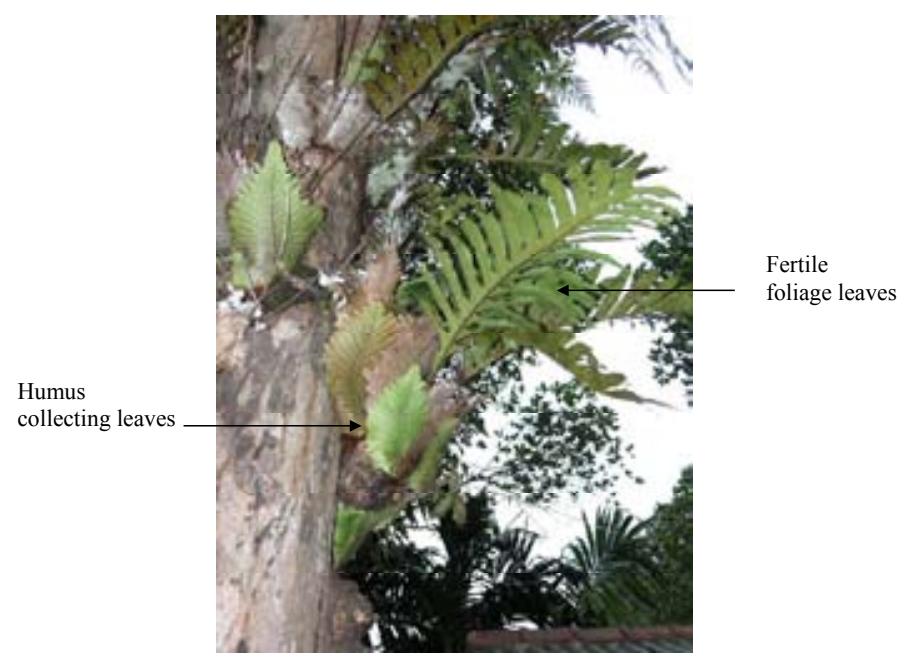

Plate 1: Drynaria quercifolia, on tree trunk of boundary of the Sinharaja forest

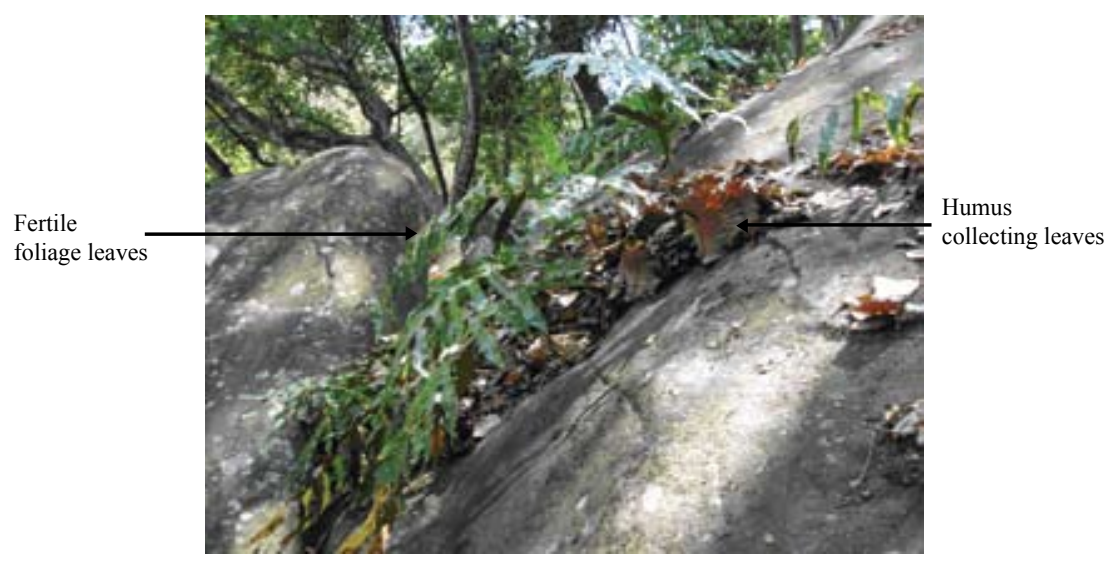

Plate 2: Drynaria sparsisora, on rock around river rine vegetation of the lower Hantana area 
two irregular rows between the connecting veins (Figure 2B). In comparison, the sori of D. quercifolia are arranged in two regular rows parallel and close to the veins (Figure 2A). The pattern of sori arrangement is considered as one of the unique and strong characters which can be used to differentiate the two species.

Scale characters and information of the previously described specimens suggest that the observed specimens from the lower Hantana area were those of $D$. sparsisora. Morphological observations of the occurrence and characters of sori as well as molecular and cytological studies of the observed specimens are being conducted to confirm that the observed specimens are that of D. sparsisora.

\section{Acknowledgement}

Authors convey their gratitude to Dr. Peter Hovenkamp, Rijksherbarium, Leiden, Netherlands for his generosity in providing the draft version of family Polypodiaceae in Sri Lanka. The support of staff members of the National Herbarium of the Royal Botanical Gardens, Peradeniya is greatly acknowledged. Special thanks go to Mr. Janaka Kandepola for preparation of illustrations.

\section{References}

1. Roos M. (1996). Mapping the world pteridophyte diversity - syetematic and flora. In: Pteridophytes in perspectives R.J. (Eds. J.M. Camus, M. Gibby \& Johns). pp. 29-42. Royal Botanical Gardens, Kew, UK.

2. Dhanasekara D.M.U.B. (Undated). Current Taxonomic Status of Ferns in Sri Lanka. Royal Botanical Gardens, Peradeniya.

3. Sledge W.A. (1981a). An annotated checklist of the pteridophytes of Ceylon. Botanical Journal of the Linnaean Society 84: 1-30.

4. Abeygunawardena P. \& Wickramasinhe W.A.R. (1991). An economic evaluation of non timber products of Hantana forest. In: Multipurpose trees in Sri Lankaresearch and development. Proceedings of the Second
Regional Workshop on Multipurpose Trees (Ed. H.P.M. Gunasena) pp. 183-190.

5. Philippa B. (1995). A management plan for upper Hantana catchment forest. Oxford Forestry Institute-University of Peradeniya Link Project. University of Peradeniya, Peradeniya.

6. Sledge W.A. (1972). The Tectarioid ferns of Ceylon. Kew Bulletin 27(3): 423-424.

7. Sledge W.A. (1981b). Thelypteridaceae of Ceylon. British Museums (Natural History) 8(1): 46-47.

8. Perera G.A.D., Withanachchi I. \& Ranasinghe S.W. (2002). Diversity of terrestrial fern species in a sub montane secondary forest at upper Hantana. Forestry and Environment Symposium. Abstract of Presentations. University of Sri Jayaewardenapura, Gangodawila, Nugegoda.

9. Subasinghe S.J.A.V., Wijethunga A.S.C.D. \& Abeygunasekera R.M.K. (2004). Diversity of fern and fern allies in five tree dominant habitats of the Hantana range. Peradeniya University Research Sessions (PURSE). University of Peradeniya. Peradeniya.

10. Sledge W.A. (1960). The Polypodiaceae and Grammitidaceae of Ceylon. Bulletin of the British Museums (Natural History), 2(5) 144-145.

11. Linnaeus C.V. (1747). Flora Zeylanica, Holmiae.

12. Winter W.P. \& Amoroso V.B. (2003). Plant resources of Southeast Asia. Cryptogams: ferns and fern allies. Backhuys Publications, Leiden. 15(2): 100-105.

13. Ranil R.H.G., Pushpakumara D.K.N.G., Wijesundera D.S.A. \& Dhanasekara D.M.U.B. (2005). Uses of Pteridophyte flora in Sri Lanka. Proceedings of the Tenth Annual Forestry and Environmental Symposium. Department of Forestry and Environmental Science, University of Sri Jayawardenapura. Gangodawila Nugegoda.

14. Beddome R.H. (1883). Handbook to the Ferns of British India, Ceylon and the Malay Peninsula. Thacker Spink and Company, Calcutta, India.

15. Hovenkamp P. (2006). Polypodiaceae. In: A Revised Handbook of the Flora of Ceylon. Volume XV. Part B. pp. 312-315.

16. Beddome R.H. (1866). The Ferns of British India. Madras, India.

17. Santhosh N. \& Madhusoodanan P.V. (1998). Fern Flora of South India: Taxonomic Revision of Polypodioid Ferns. Daya Publishing House, Delhi, India. 